\title{
THE CONTRIBUTION OF GOVERNMENT SPONSORED HEALTH INSURANCE SCHEMES TOWARDS INDIAN HEALTH SECTOR
}

\author{
*Dr.V.Pugazhenthi \\ * Controller of Examinations, Associate Professor \& HOD of Commerce, \\ Rajah Serfoji Government College, Thanjavur-5
}

Article DOI: https://doi.org/10.36713/epra6458

\begin{abstract}
Today, there are thirty four general insurance companies including the Export Credit Guarantee Corporation of India Ltd (ECGC) and Agriculture Insurance Corporation (AIC) of India and 24 life insurance companies operating in the country. Barring the AIC and ECGC, all other 32 insurers transact health insurance business, of whom six are stand-alone health insurers. Although there are number of insurers and different types of health insurance products available in the market, three-fourth health-insured Indians still gets covered only by a government-sponsored health insurance scheme (GSHIS) like PMJAY. Of all the health insurance premiums underwritten in the year 2019-20, 10 per cent came only from the GSHIS. In terms of number of persons covered, 73 per cent health-insured people are governed by one or other GSHIS. Looking at the profitability of the health insurer also, the incurred claims ratio is just 97.22 per cent in GSHISs. Thus, the health insurance premium, penetration and profitability-all of these are significantly sponsored and subsidized by the government through GSHIS, incorporating the public-private partnership (PPP) mode. This article details the role of GSHIS in the health insurance segment, taking the performances of the Indian health insurance sector in the year 2019-20.
\end{abstract}

KEYWORDS: Government sponsored health insurance schemes, health insurance, health premium, incurred claims ratio, insurance, insurance regulatory and development authority, standalone health insurers.

\section{JEL Classifications: I13, I18}

The contribution of Government Sponsored Health Insurance Schemes towards Indian Health Sector

According to the sigma research publication on world insurance by the Swiss Re Institute, insurance markets were on a solid growth path before the COVID-19 pandemic, with total global direct premium written increased near three per cent in 2019 from the year before. In India also, on the one hand, Life insurance industry recorded a premium income of Rs.5.73 lakh crore during 2019-20 as against Rs.5.08 lakh crore in the previous financial year, registering growth of 12.75 per cent. On the other hand in the General Insurance sphere also, out of 28 private insurers operating in India, 24 insurers reported an increase in premium underwritten in the year 2019-20 as compared to the previous year.

During the year 2019-20, General and Health Insurance companies collected a Rs.50,758 crore as Health Insurance premium (excluding Personal Accident and Travel Insurance premium) registering a growth of 13 per cent over the previous year. The four 


\section{SJIF Impact Factor 2021: 7.13| ISI I.F.Value:1.241| Journal DOI: 10.36713/epra2016 $\quad$ ISSN: 2455-7838(Online) EPRA International Journal of Research and Development (IJRD)}

public sector general insurers continued to hold a larger market share with 49 per cent during the year 2019-20. However, there was a reduction in the market share of public sector insurers from 52 per cent in 2018-19.

The health insurance segment has witnessed a spectacular growth during the last decade which is substantially higher than the Compounded Annual Growth Rate (CAGR) of non-health non-life segment growt. But the contribution of Government Sponsored Health Insurance Schemes (GSHISs) through the Public Private Partnership (PPP) to this growth is to be realized and recognized at this juncture.

Of all the health insurance premiums underwritten in the year 2019-20, 9.69\% came only from the GSHIS. In terms of number of persons covered, $73 \%$ health insured people are governed by one or other the GSHIS. Looking at the profitability of the health insurer also, the incurred claims ratio is just $97.22 \%$ in GSHISs. Thus the health insurance premium, penetration and profitability- all these are significantly sponsored and subsidised by the Government through GSHIS, incorporating the PPP mode. This paper deals with the role of GSHIS in the Health insurance segment in detail, taking the performances of the Indian health insurance sector in the year 2019-20.

Till the end of the last decade, health insurance was generally meant for rich and even to them mainly as a mode of evading income tax. The entry of private sector, meticulously guided by the IRDA and the introduction of GSHISs changed the whole scenario. In an environment challenged by low public financing for health, entrenched accountability issues in the public delivery system, and the persistent predominance of out-of-pocket spending, particularly by the poor, GSHISs have introduced a new set of arrangements to govern, allocate, and manage the use of public resources for health, including an explicit package of services, greater accountability for results, and a "built-in" bottom-up design to reach universal coverage by first covering the poor. In 2010, about 240 million Indians were covered by GSHISs. (LaForgia,Gerard, and Somil Nagpal, 2012). There are a number of GSHISs launched in the recent years including Rashtriya Swasthya Bima Yojana (RSBY), Rajiv Aarogyashri in Andhra Pradesh, Vajpaye e Arogyashri in Karnataka, RSBY Plus in Himachal Pradesh, Apka Swasthya Bima Yojana (ASBY) in Delhi, and Chief Minster's Comprehensive Health Insurance Schemes in Tamil Nadu. Now, all these schemes were integrated with the ABPMJAY and 50 crore people got covered by the
GSHISs alone which strengthens supplements the Indian Health Insurance Industry substantially.

\section{Pradhan Mantri Jan Arogya Yojana}

To top all the Government Sponsored Health Insurance Schemes, the world's largest health insurance scheme with the aim of offering universal coverage for the nth Indian, Pradhan Mantri Jan Arogya Yojana (PM-JAY) was launched on September 23 , 2018. It is a flagship scheme of Government of India under Ayushman Bharat scheme providing a health cover of five lakh rupees per family per year for secondary and tertiary care hospitalization to poor and vulnerable households. PM-JAY was earlier known as the National Health Protection Scheme (NHPS) which subsumed the Rashtriya Swasthya Bima Yojana (RSBY) which had been launched in 2008. The scheme is fully funded by the Government and cost of implementation is shared between the Central and State Governments.

Other Government Sponsored Socially Oriented Insurance Schemes include Pradhan Mantri Fasal Bima Yojana (PMFBY) and Restructured Weather Based Crop Insurance Scheme (RWBCIS)2016, Pradhan Mantri Jeevan Jyoti Bima Yojana (PMJJBY), a government subsidized one year cover Term Life Insurance Scheme to people in the age group of 18 to 50 years having a bank account who give their consent to join / enable auto-debit for the life cover of two lakh rupees, Pradhan Mantri Jan Dhan Yojana (PMJDY) with an extended accidental insurance cover up to two lakh rupees, Pradhan Mantri Suraksha Bima Yojana (PMSBY) which is available to people in the age group 18 to 70 years with a bank account upto two lakh rupees for accidental death and full disability and one lakh rupee for partial disability and Pradhan Mantri Vaya Vandana Yojana (PMVVY) which is to protect elderly persons and to provide social security during old age.

\section{Compound Annual Growth Rate of GSHIS}

Though the figures for the number of the persons covered and gross health premium underwritten under the GSHIS fluctuate in the past decade, nearly three fourth of the health insured in all the years were covered so only by GSHISs. On account of conservative nature of health cover offered under GSHISs, the Government health premiums in this period grew only with a CAGR of $11.98 \%$ whereas the total health segment premium grew with a CAGR of $18.66 \%$ in the bygone decade. 


\section{EPRA International Journal of Research and Development (IJRD)}

Volume: 6 | Issue: 2 | February 2021

- Peer Reviewed Journal

Table No.1: Number of Persons and Gross Premium in Government Sponsored Health Insurance Schemes

\begin{tabular}{|c|c|c|c|c|c|c|}
\hline \multirow{3}{*}{ YEAR } & \multirow{2}{*}{\multicolumn{2}{|c|}{ GSHIS* }} & \multicolumn{2}{|c|}{ No. of persons in 'Lakhs } & \multicolumn{2}{|c|}{ Premium in Rs. Crores } \\
\hline & & & TOT & & $\begin{array}{r}\text { RATIO O } \\
\text { TO }\end{array}$ & $\begin{array}{l}\text { SSHIS TO } \\
\mathrm{L}^{* *}\end{array}$ \\
\hline & $\begin{array}{c}\text { No. of Persons } \\
\text { in lakhs }\end{array}$ & $\begin{array}{c}\text { Premium in } \\
\text { crores }\end{array}$ & $\begin{array}{c}\text { No. of Persons in } \\
\text { lakhs }\end{array}$ & $\begin{array}{c}\text { Premium in } \\
\text { crores }\end{array}$ & $\begin{array}{c}\text { No. of } \\
\text { Persons }\end{array}$ & $\begin{array}{c}\text { Premiu } \\
\text { m }\end{array}$ \\
\hline $2009-10$ & 1674 & 1587 & N.A. & 8109 & N.A. & $20 \%$ \\
\hline $2010-11$ & 1891 & 2198 & 2535 & 11030 & $75 \%$ & $20 \%$ \\
\hline 2011-12 & 1612 & 2225 & 2118 & 13069 & $76 \%$ & $17 \%$ \\
\hline $2012-13$ & 1494 & 2347 & 2073 & 15452 & $72 \%$ & $15 \%$ \\
\hline 2013-14 & 1553 & 2082 & 2162 & 17495 & $72 \%$ & $12 \%$ \\
\hline $2014-15$ & 2143 & 2425 & 2880 & 20096 & $74 \%$ & $12 \%$ \\
\hline $2015-16$ & 2733 & 2474 & 3590 & 24448 & $76 \%$ & $10 \%$ \\
\hline $2016-17$ & 3350 & 3,090 & 4375 & 30392 & $77 \%$ & $10 \%$ \\
\hline 2017-18 & 3593 & 3981 & 4820 & 37029 & $75 \%$ & $11 \%$ \\
\hline 2018-19 & 3571 & 5672 & 4720 & 44873 & $76 \%$ & $13 \%$ \\
\hline $2019-20$ & 3,620 & 4921 & 4,987 & 50,758 & $73 \%$ & $10 \%$ \\
\hline CAGR & $8.02 \%$ & $11.98 \%$ & $7.81 \%$ & $18.66 \%$ & & \\
\hline
\end{tabular}

Source:* Source: Compiled from the Various Annual reports of IRDA **Authors' calculations

\section{GSHIS Penetration}

In the following paragraphs, the performance of the GSHISs in the year 2019-20 is analysed taking four parameters namely, the number of persons, number of policies, gross premium underwritten and incurred claims ratio. For the purpose of present analysis Travel and personal accident insurances and health policies carried-out in foreign countries are not considered as health insurance policies.

Table No.2: Health Insurance Business of General and Health Insurers: Class of Business-wise

\begin{tabular}{|c|c|c|c|c|c|c|c|}
\hline \multirow{2}{*}{ Class of Business } & \multirow{2}{*}{ Item } & \multicolumn{2}{c|}{ No.of Policies in Lakhs } & \multicolumn{2}{c|}{ No of Lives in Lakhs } & \multicolumn{2}{c|}{ Gross Premium in Crores } \\
\cline { 2 - 8 } & & $\mathbf{2 0 1 8 - 1 9}$ & $\mathbf{2 0 1 9 - 2 0}$ & $\mathbf{2 0 1 8 - 1 9}$ & $\mathbf{2 0 1 9 - 2 0}$ & $\mathbf{2 0 1 8 - 1 9}$ & $\mathbf{2 0 1 9 - 2 0}$ \\
\hline \multirow{4}{*}{$\begin{array}{c}\text { Government } \\
\text { Business }\end{array}$} & No./ Premium & 0.003 & 0.002 & 3571.17 & 3619.71 & 5672.1 & 4920.62 \\
\cline { 2 - 8 } & Growth(\%) & -3.04 & -4.71 & -0.60 & 1.36 & 42.47 & -13.25 \\
\cline { 2 - 8 } & Share(\%) & 0.001 & 0.001 & 75.65 & 72.58 & 12.64 & 9.69 \\
\hline \multirow{4}{*}{$\begin{array}{c}\text { Group Business } \\
\text { (Excl. Govt } \\
\text { Business) }\end{array}$} & No./ Premium & 10.90 & 7.61 & 728.54 & 935.17 & 21676.01 & 25880.83 \\
\cline { 2 - 8 } & Growth(\%) & 68.78 & -30.20 & -18.55 & 28.36 & 22.08 & 19.40 \\
\cline { 2 - 8 } $\begin{array}{c}\text { Individual } \\
\text { Business }\end{array}$ & Share(\%) & 5.27 & 4.24 & 15.43 & 18.75 & 48.31 & 50.99 \\
\cline { 2 - 8 } & Growth(\%) & 39.11 & -12.35 & 26.41 & 2.76 & 14.61 & 13.88 \\
\cline { 2 - 8 } & Share(\%) & 94.73 & 95.76 & 8.91 & 8.67 & 39.05 & 39.32 \\
\hline \multirow{4}{*}{ Total } & No./ Premium & 206.82 & 179.33 & 4720.35 & 4987.13 & 44872.76 & 50758.07 \\
\cline { 2 - 8 } & Growth(\%) & 40.41 & -13.29 & -2.06 & 5.65 & 21.18 & 13.12 \\
\cline { 2 - 8 } & Share(\%) & 100 & 100 & 100 & 100 & 100 & 100 \\
\hline
\end{tabular}

Source:IRDA Annual report 2019-20 p.58

Number of GSHIS policies

Of all the 179.33 lakhs number of policies, only 0.02 lakhs policies were underwritten in favour of GSHISs in the year 2012-13. As all the GSHISs' policies are group ones, the number accounts for only around a quarter per cent of the total. 


\section{SJIF Impact Factor 2021: 7.13| ISI I.F.Value:1.241| Journal DOI: 10.36713/epra2016 \\ ISSN: 2455-7838(Online) \\ EPRA International Journal of Research and Development (IJRD)}

Volume: 6 | Issue: 2 | February 2021

- Peer Reviewed Journal

Number of Persons Covered under GSHIS

Nearly 498.71 million Indians were now by one or other health insurance policy in the 2019-20 out of which nearly 361.97 million Indians are covered by GSHISs. In other words, the GSHISs alone gave coverage to $73 \%$ health insured Indians.

Health Premium under GSHIS

In the year 2019-20 a total of 507.58 billion rupees of health premium was received by Indian Insurance sector. In the same year, the central and state Governments paid 49.21 billion rupees as premium to the insurers under GSHISs. In other words, around 10\% of health insurance premium comes from the exchequer to give health cover to the poor Indians.
The segment-wise insurer-wise data is available only till the year 2017-18. The segment wise data classification for this year says that $9 \%$ of the total health premium received by the multiline private sector non life insurers, $13 \%$ of the health premium of the public sector non life insurers and $1 \%$ of the premium of the standalone health insurers are towards the cover by GSHISs. Further comparing with the total health premium of each insurer, a whopping $49 \%$ of the gross premium income of Reliance General Insurance, came only from GSHISs being highly benefitted from the Government's commitment to provide healthcare cover to everyone.

Table No.3: Net Incurred Claims Ratio of select Insurers for 2017-18 in GSHIS

(Excluding Travel -Domestic/Overseas and Personal Accident Insurance)

(Net Earned Premium \& Net Incurred Claims in ₹ Lakh)

\begin{tabular}{|c|c|c|c|c|c|c|}
\hline \multirow{2}{*}{ Select Insurers } & \multicolumn{2}{|c|}{ Government Sponsored Schemes } & \multicolumn{2}{c|}{ TOTAL } \\
\cline { 2 - 7 } & $\begin{array}{c}\text { Net Earned } \\
\text { Permium }\end{array}$ & $\begin{array}{c}\text { Claims } \\
\text { Incurred } \\
\text { (Net) }\end{array}$ & $\begin{array}{c}\text { Incurred } \\
\text { Claims } \\
\text { Ratio (Net) }\end{array}$ & $\begin{array}{c}\text { Net Earned } \\
\text { Permium }\end{array}$ & $\begin{array}{c}\text { Claims } \\
\text { Incurred } \\
\text { (Net) }\end{array}$ & $\begin{array}{c}\text { Incurred } \\
\text { Claims } \\
\text { Ratio (Net) }\end{array}$ \\
\hline Bajaj Allianz & 3179 & 4072 & $128 \%$ & 106917 & 93091 & $87 \%$ \\
Future Generali & 232 & 408 & $176 \%$ & 16107 & 16407 & $102 \%$ \\
ICICI Lombard & 3704 & 3990 & $108 \%$ & 111458 & 86485 & $78 \%$ \\
IFFCO Tokio & 9051 & 6059 & $67 \%$ & 44454 & 39374 & $89 \%$ \\
Reliance & 28763 & 34420 & $120 \%$ & 58741 & 67190 & $114 \%$ \\
Private Total & $\mathbf{4 4 9 2 9}$ & $\mathbf{4 8 9 4 9}$ & $\mathbf{1 0 9 \%}$ & $\mathbf{5 0 7 9 3 5}$ & $\mathbf{4 0 6 0 1 7}$ & $\mathbf{8 0 \%}$ \\
National & 92276 & 105809 & $115 \%$ & 374353 & 436262 & $117 \%$ \\
New India & 71364 & 81528 & $114 \%$ & 589698 & 613265 & $104 \%$ \\
Oriental & 2982 & 3913 & $131 \%$ & 341368 & 349409 & $102 \%$ \\
United India & 59441 & 70810 & $119 \%$ & 441981 & 491640 & $111 \%$ \\
Public Total & $\mathbf{2 2 6 0 6 2}$ & $\mathbf{2 6 2 0 6 0}$ & $\mathbf{1 1 6} \%$ & $\mathbf{1 7 4 7 4 0 0}$ & $\mathbf{1 8 9 0 5 7 6}$ & $\mathbf{1 0 8 \%}$ \\
Max Bupa & 378 & 346 & $92 \%$ & 57034 & 28613 & $50 \%$ \\
Religare & 725 & 1025 & $141 \%$ & 57050 & 32477 & $57 \%$ \\
Star Health & 2469 & 2133 & $86 \%$ & 265699 & 165257 & $62 \%$ \\
SAHI Total & $\mathbf{3 5 7 2}$ & $\mathbf{3 5 0 4}$ & $\mathbf{9 8 \%}$ & $\mathbf{5 3 2 1 8 9}$ & $\mathbf{3 2 8 1 2 9}$ & $\mathbf{6 2 \%}$ \\
Grand Total & $\mathbf{2 7 4 5 6 3}$ & $\mathbf{3 1 4 5 1 3}$ & $\mathbf{1 1 5 \%}$ & $\mathbf{2 7 8 7 5 2 4}$ & $\mathbf{2 6 2 4 7 2 2}$ & $\mathbf{9 4 \%}$ \\
\hline
\end{tabular}

Source: Compiled from the Various Annual reports of IRDA

Among the public sector insurers, National Insurance Company is the prime beneficiary receiving $25 \%$ of its premium income just from the GSHISs. Every standalone health insurer is in receipt of $1 \%$ of its premium income so.

Looking at the pay-out destinations of the total premium paid under the Government Sponsored Health Insurance Scheme in the year 2017-18, the public sector insurers collectively received $82 \%$ of the premium of GSHISs, followed by the multiline private sector insurers receiving $16 \%$ and standalone private sector insurers receiving the rest $1 \%$ of the premiums paid for GSHISs. The insurer-wise analysis of the premium payments in 2017-18 reveals that a high $34 \%$ of the GSHIS premiums went into the hands of the National Insurance Company, followed by the New India Assurance Company receiving 26\% of the GSHIS premiums. It shows how the GSHISs help the market leaders to sustain their positions.

\section{Incurred Claims Ratio of GSHIS}

The incurred claims ratio is the ratio between the Net Earned Premium and Net Premium Incurred. There is an improvement in Incurred Claims Ratio of health business excluding Personal Accident 


\section{SJIF Impact Factor 2021: 7.13| ISI I.F.Value:1.241| Journal DOI: 10.36713/epra2016 \\ ISSN: 2455-7838(Online) \\ EPRA International Journal of Research and Development (IJRD) \\ Volume: 6 | Issue: 2 | February 2021 \\ - Peer Reviewed Journal}

and Travel Insurance Business from 91 per cent in the year 2018-19 to 88 per cent in the year 2019-20. The incurred claims ratio of public sector insurers improved from 105 per cent in 2018-19 to 102 per cent in 201920 and for private sector insurers improved from 84 per cent in 2018-19 to 82 per cent in 2019-20. (IRDA, 2020).

This ratio for the total health insurance business in the year $2019-20$ was $88.43 \%$ and the claim ratio for the GSHISs was $97.22 \%$. This means that the health insurers in Indian health insurance industry stood obviously gained by the GSHISs all through the years till 2019-20. While private sector multiline health insurers' incurred claims ratio was $82.19 \%$, the claim ratio of GSHISs of theirs was $96.74 \%$. Though the health segment burnt the fingers of public sector insurers with $102 \%$ claim ratio, the same under the GSHISs component was just $99 \%$ in 201920.

Table No.4: Incurred Claims Ratios of Indian Health insurers in 2019-20

\begin{tabular}{|c|c|c|c|c|c|c|c|c|}
\hline \multirow[b]{2}{*}{ Class of Business } & \multicolumn{2}{|c|}{$\begin{array}{c}\text { Government } \\
\text { Business }\end{array}$} & \multicolumn{2}{|c|}{$\begin{array}{c}\text { Group } \\
\text { Business } \\
\end{array}$} & \multicolumn{2}{|c|}{$\begin{array}{c}\text { Individual } \\
\text { Business } \\
\end{array}$} & \multicolumn{2}{|c|}{ Total } \\
\hline & $\begin{array}{c}2018- \\
19\end{array}$ & $\begin{array}{l}2019- \\
20\end{array}$ & $\begin{array}{c}2018- \\
19\end{array}$ & $\begin{array}{l}2019- \\
20\end{array}$ & $\begin{array}{c}2018- \\
19\end{array}$ & $\begin{array}{l}2019- \\
20\end{array}$ & $\begin{array}{c}2018- \\
19\end{array}$ & $\begin{array}{l}2019- \\
20\end{array}$ \\
\hline Public Sector Insurers & 86.27 & 99.45 & 114.78 & 106.18 & 90.35 & 91.73 & 104.99 & 101.54 \\
\hline Private Sector Insurers & 92.62 & 96.74 & 91.34 & 87.19 & 65.99 & 66.53 & 84.01 & 82.19 \\
\hline $\begin{array}{c}\text { Stand-alone Health } \\
\text { Insurers }\end{array}$ & 182.21 & 78.4 & 78.48 & 85.82 & 56.55 & 59.18 & 62.73 & 66.16 \\
\hline Total & 90.18 & 97.22 & 104.98 & 98.84 & 72.13 & 72.86 & 90.96 & 88.43 \\
\hline
\end{tabular}

Source: Compiled from the Various Annual reports of IRDA

The ICR for the year 2017-18 of the Indian Health Sector's GSHISs was at $115 \%$ which is contributed by public sector at $116 \%$, by the private sector at $109 \%$ and by the Stand Alone Health Insurance sector 98\%, signifying the public sector's justifying role of public welfare in delivering the GSHISs. On the other hand, the overall ICR for the year 2017-18 of the Indian Health Sector's was only at $94 \%$ which is contributed by public sector at $108 \%$, by the private sector at $80 \%$ and by the Stand Alone Health Insurance sector $62 \%$.

The trend analysis also reveals that the ICR of the GSHISs keeps on going north right from the year 2013-14. It has been on steady increase from $93.2 \%$ in $2013-14$ to $122 \%$ in $2016-17$ and was at $115 \%$ in 2017 18 after a slight recovery from the private and public sector general insurers.

Table No.5: INCURRED CLAIMS RATIO OF GSHIS FROM 2013-14 TO 2017-18

\begin{tabular}{|c|c|c|c|c|c|}
\hline GSHIS & $2013-14$ & $2014-15$ & $2015-16$ & $2016-17$ & $2017-18$ \\
\hline Private Total & $\mathbf{7 9 . 6} \%$ & $\mathbf{8 7 . 7} \%$ & $\mathbf{8 2 . 0} \%$ & $\mathbf{1 1 5 \%}$ & $\mathbf{1 0 9 \%}$ \\
\hline Public Total & $\mathbf{1 0 5 . 5} \%$ & $\mathbf{1 1 6 . 5 \%}$ & $\mathbf{1 1 7 . 3} \%$ & $\mathbf{1 2 4 \%}$ & $\mathbf{1 1 6 \%}$ \\
\hline SAHI Total & $\mathbf{5 5 . 7} \%$ & $\mathbf{4 8 . 7} \%$ & $\mathbf{7 4 . 9} \%$ & $\mathbf{5 5 \%}$ & $\mathbf{9 8 \%}$ \\
\hline Grand Total & $\mathbf{9 3 . 2 \%}$ & $\mathbf{1 0 7 . 7} \%$ & $\mathbf{1 0 9 . 2 \%}$ & $\mathbf{1 2 2 \%}$ & $\mathbf{1 1 5 \%}$ \\
\hline
\end{tabular}

Source: Compiled from the Various Annual reports of IRDA 
FIG 1: INCURRED CLAIMS RATIO OF HEALTH INSURANCE IN 2017-18

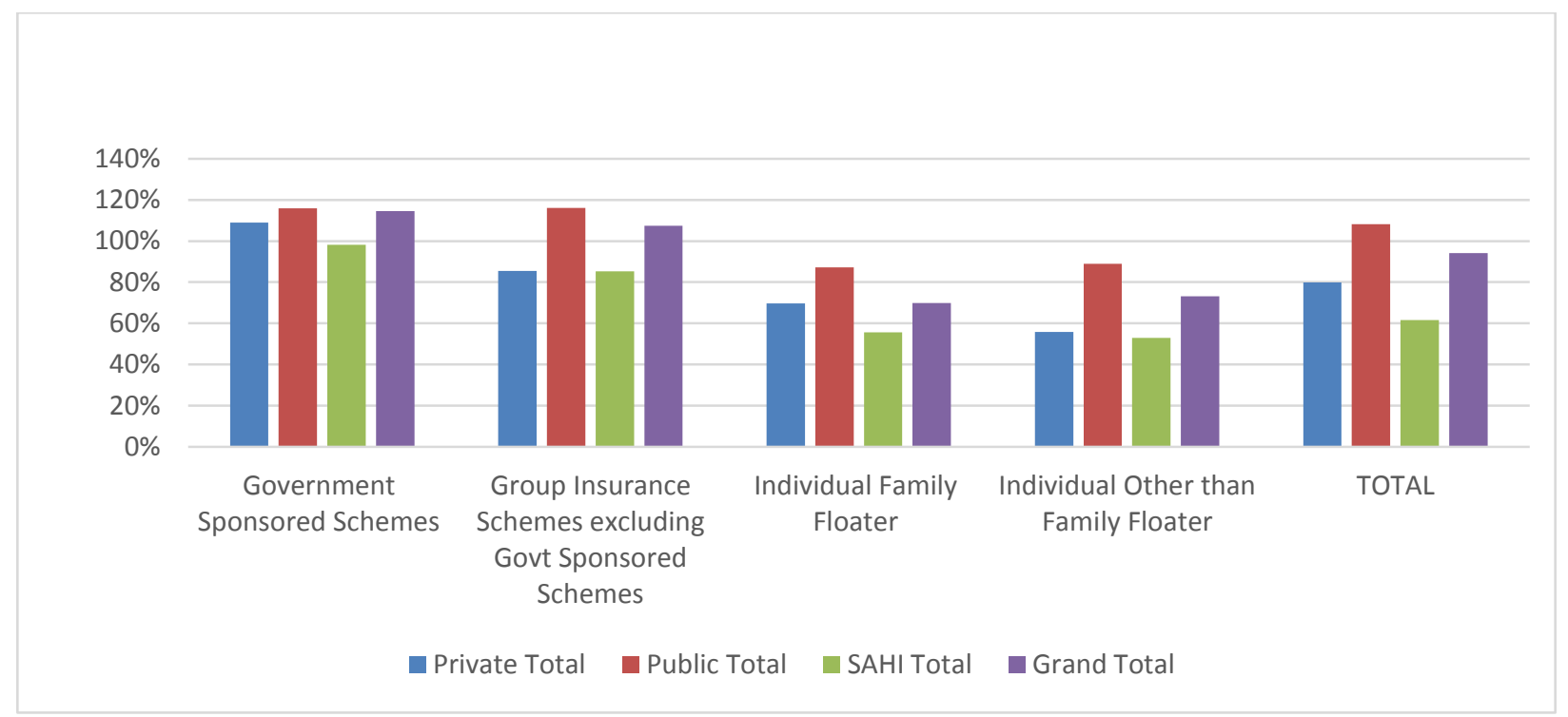

Source: Compiled from the Various Annual reports of IRDA

FIG. 2: INCURRED CLAIMS RATIO OF GSHIS FROM 2013-14 TO 2017-18

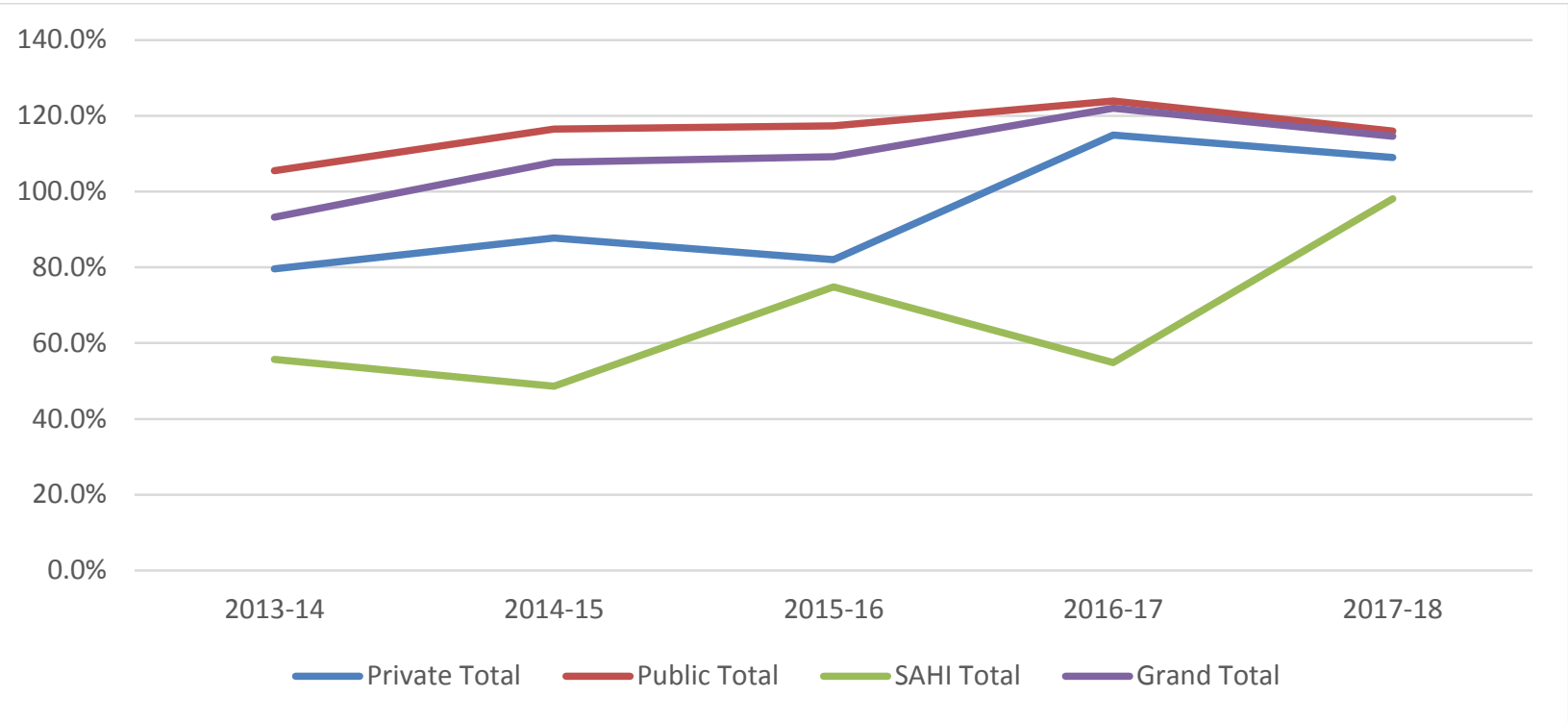

Source: Compiled from the Various Annual reports of IRDA

\section{CONCLUSION}

Worldwide every year 150 million people face catastrophic health-care costs because of direct payments, while 100 million are pushed into poverty the equivalent of three people every second $(\mathrm{Xu}, \mathrm{K}$,et al., 2007). Though the Universal Health Coverage is considered as a utopian panacea to this problem, the compulsory enrolment of at least the BPL people, completely funded by the Government is a welcome step towards the justification of the welfare state 


\section{SJIF Impact Factor 2021: 7.13| ISI I.F.Value:1.241| Journal DOI: 10.36713/epra2016 $\quad$ ISSN: 2455-7838(Online) EPRA International Journal of Research and Development (IJRD)}

Volume: 6 | Issue: 2 | February 2021

- Peer Reviewed Journal

concept. At the same time, the voluntary health insurance for the above-BPL population should also be encouraged by the Government and the Authority.

The above analysis about the GSHISs figures figure out the fact that the Government not only helps the poor people to get health cover but also help the health insurers to improve their revenue figures. It also helps the health insurers in another way by insuring the BPL families and thus creating sense of need for health insurance among the uninsured-above-BPL population which could be tapped by the insurers in the course of time. Here, the role of IRDA is increasingly needed since the GSHISs breed their own inherent inefficiencies and complications. On the one hand portability and standardization movements bring harmonisation in the health insurance segment, paving for country-wide uniformity and better transparency. On the other hand GSHISs flourish with different size and shape, as each GSHIS is different and tailor-made. For example, the state government sponsored health insurance scheme in Tamil Nadu reserves certain treatments only to the Government Hospitals and not to the private hospitals while other schemes do not insist so. Similarly each GSHIS is subject to positive change with increased sum assured, increased treatment coverage and better hospital network every now and then. The replacement of the 'Chief Minister Kalaignar's Insurance Scheme for Life Saving Treatments -2009' by the 'Chief Minister's Comprehensive Health Insurance Scheme-2011' in Tamil Nadu is the perfect example to the dynamism of GSHISs. Now all the GSHISs are brought under one umbrella PMJAY.

Though GSHISs for those below the poverty line is widely praised as a success but offers limited financial protection, suffers from corruption, abuse, and cost escalation, and has skewed public resources to curative rather than preventative care (Balooni K,et $\mathrm{al}, 2012)$. The very nature of Government interventions, heterogeneity in operations and beneficiaries considering the GSHIS as yet another subsidy, not realizing the very nature of health insurance, make the system uncontrollable. For example the proof for BPL family to be given to obtain the smartcard and for getting treatment is decided by the State Government in case of State Government Sponsored Health Insurance Schemes. The complaint of denial of the treatment because of inadequacy of the proof or other reasons can be handled only by the Appellate authorities constituted for that purpose. Whatever be the case, the GSHISs need applause for disseminating the concept of health insurance to fifteen crore people in a very short span of time and making quality health care affordable to all and thus ensuring the Gross Domestic Healthiness.

Acknowledgement: This paper is part of the research work of the major research project sponsored by ICSSR to the author.

\section{REFERENCES}

1. Balooni $K$, Gangopadhyay $K$, Turakhia $S$ and Karthik RG. (2012) 'Challenges in the Sustainability of a Targeted Health Care Initiative in India' IIM Kozhikode Society \& Management Review, 1(1):21-32.

2. IRDA, Annual Report, 2019-20 Retrieved from: http://www.irda.gov.in/ADMINCMS/cms/frmGener al_Layout.aspx?page $=$ PageNo2159\&flag=1\&mid $=$ Annual reports $\gg$ Annual reports of the Authority

3. La Forgia, G and Nagpal, S (2012) 'Governmentsponsored health insurance in India: Are you covered?' The World Bank, Washington D.C.

4. Pugazhenthi V and Sunitha C, (2015), "The Government-sponsored Health Insurance Schemes for the Gross Domestic Healthiness", Journal of Health Management, Dec.2015

5. https://doi.org/10.1177/0972063415606276

6. Shivakumar, G. (2013) 'Government paid private insurer crores in premium for ghost beneficiaries' The Hindu Online [online] 2 September 2013. Retrieved from: http://www.thehindu.com/news/national/governmen t-paid-private-insurer-crores-in-premium-forghostbeneficiaries/article5083382.ece?homepage $=$ true.

7. Sinha $K$ (2012) 'Unnecessary procedures on the rise in governmentt hospitals too: Report' The Times of India [online] 15 October 2012. Retrieved from:

http://timesofindia.indiatimes.com/india/Unnecessa ry-procedures-on-the-rise-in-govt-hospitals-tooReport/articleshow/16816263.cms?referral $=P M$

8. Xu, $K$, Evans D, Carrin $G$, Aguilar-Rivera AM, Musgrove P, Evans $T$ (2007) 'Protecting households from catastrophic health spending' Health Affairs, 26(4): 972-983. 